Loeb, M., \& Alluisi, E. A. (1984). Theories of vigilance. In J. S. Warm (Ed.), Sustained attention in human performance (pp. 179-205). Chichester, U.K.: Wiley.

Mackworth, N. H., Kaplan, I. T., \& Metlay, W. (1964). Eye movements during vigilance. Perceptual \& Motor Skills, 18, 397-402.

Parasuraman, R. (1973). Vigilance and attention: A psychophysiological study. Unpublished master's thesis, University of Aston in Birmingham, Birmingham, U.K.

Parasuraman, R., Warm, J. S., \& Dember, W. N. (1987). Vigilance: Taxonomy and utility. In L. S. Mark, J. S. Warm, \& R. L. Huston (Eds.), Ergonomics and human factors: Recent research (pp. 11-32). New York: Springer-Verlag.

WARM, J. S. (in press). Vigilance and target detection. In B. M. Huey \& C. D. Wickens (Eds.), Teams in transition. Washington, DC: National Academy Press.
Warm, J. S., Chin, K., Dittmar, M. L., \& Dember, W. N. (1987). Effects of head restraint on signal detectability in simultaneous and successive vigilance tasks. Journal of General Psychology, 114, 423-431.

Warm, J. S., EpPS, B. D., \& Ferguson, R. P. (1974). Effects of knowledge of results and signal regularity on vigilance performance. Bulletin of the Psychonomic Society, 4, 272-274.

WARM, J. S., \& JERISON, H. J. (1984). The psychophysics of vigilance. In J. S. Warm (Ed.), Sustained attention in human performance (pp. 15-59). Chichester, U.K.: Wiley.

WiCKens, C. D. (1991). Processing resources and attention. In D. L. Damos (Ed.), Multiple-task performance (pp. 3-34). London: Taylor \& Francis.

(Manuscript received February 19, 1992.)

\title{
The Australia Prize
}

The Australia Prize is an international award given by the Government of the Commonwealth of Australia for an outstanding specific achievement in a selected area of science and technology promoting human welfare. In this context, science encompasses natural and technological sciences, engineering, and mathematics. A prize is $\$ A 250,000$, together with an inscribed medal.

The Australia Prize Committee consists of the Presidents of the Australian Academy of Science and the Australian Academy of Technological Sciences and Engineering, alternating in the Chair, and other distingished Australans. The Committee, assisted by specialist advisers, recommends on the award of the Australia Prize.

The Australia Prize acknowledges outstanding achievements by scientists and technologists, and celebrates success. To date, the awards have featured innovations based on applying science and technology to human challenges.

\section{THE 1993 AUSTRALIA PRIZE}

The 1993 Australia Prize will be awarded in the field of

\section{SENSORY PERCEPTION}

Nominations are now being sought internationally from learned bodies, universities, research institutions, and professional associations. Nominations close on July 31, 1992.

Copies of the nomination form may be obtained from the Psychonomic Society Publications Office, 1710 Fortview Road, Austin, TX 78704 (Telephone 512-462-2442).

For further information, contact the Australia Prize Secretariat at the following address: Australia Prize, GPO Box 9839, Canberra, ACT 2601, Australia (Telephone 61-6-276-1510, Fax 616-276-1827, Telex AA 62654). 